\title{
American Psycho or Postmodern Gothic
}

\author{
Sonia Baelo Allué \\ Universidad de Zaragoza
}

Throughout two centuries the term 'gothic' has undergone an evolution. Horace Walpole's Castle of Ostranto (1764) is generally considered the first gothic novel, showing a fascination with the Jacobean, medieval, sentimental and sublime. After this novel, there was a proliferation of gothic motifs such as the graveyard, the castle, spectres, monsters, corpses, monks and nuns. Ever since, horror stories have changed to adapt themselves to the atmosphere, style and setting dictated by the social reality that they have encountered. ${ }^{1}$ The 20th century has transformed some of these motifs, increasing their realism. On many occasions the modern city has replaced the gothic castle and forest and the villains are now psycho-killers. The contemporary gothic still presents narratives of darkness, desire and power, although these effects are achieved through new techniques and have extended into different genres and media. This paper focuses on one of these narratives, American Psycho, a narrative that encompasses and combines 20th-century gothic techniques and effects, together with a sharp social critique of the decade of the 80s in America.

Most critics agree that the 20th century has seen the expansion of the gothic, which is now used in a wider range of contexts: cinema, musical videos, advertisements, comics (Jancovich 83; Botting 154; Punter 119; Bloom 3). Clive Bloom even mentions the art deco of New York's skyscrapers as a real-life equivalent to the gothic castles (2). What was once a literary genre is now present in a wide range of cultural manifestations and this has produced a self-awareness of the genre. Literary characters make reference to cinematic ones. Thus, saying that cinema and literature have drunk from each other for inspiration would not be too far-fetched. The first cinematic adaptations of gothic literary classics such as Mary Shelley's Frankenstein; or, the Modern Prometheus (1818), Bram Stoker's Dracula (1897) or the adaptations of Stephen King's novels seem to confirm one side of this theory. On the other hand, these last decades have also seen how the cinematic tradition of the slasher movies, such as The Texas Chainsaw Massacre (1974), Henry, Portrait of a Serial Killer (1989) or Halloween (1978) among others, has influenced many literary writers. David Punter names Thomas Harris, Iain Banks, Will Self and Bret Easton Ellis (167-78).

American Psycho (1991) is the best known novel of Bret Easton Ellis. It reflects with great accuracy how the gothic traits have extended to embrace also other characteristics mainly developed through cinema, magazines, newspapers. The book reflects these tendencies through its own uncertain generic form, which is a trait typical of postmodern gothic

\footnotetext{
${ }^{1}$ Gothic may produce two effects: terror and horror. Terror is a mental effect, an elevation of the soul. It is positive because it reconstitutes the limits of the self and of society. On the other hand, horror is more dangerous since there is no elevation of the soul but a physical reaction. Terror developed especially in the first manifestations of the genre, nowadays horror is more widespread (Botting 9-10).
} 
and postmodern products in general. Jean-Francois Lyotard claimed that we live a postmodern condition, which is marked by a crisis in the status of knowledge in Western societies. Overarching and totalising thought has been rejected for a plurality of stories and voices, favouring heterogeneity. Out of a postmodern condition a postmodern gothic is developed, in this way there is not one type of gothic but many. The successful genre of the 19th century had to change and adapt itself to these new social situations. Fred Botting talks about postmodern gothic and states that one of its main characteristics is its uncertainty not only at the level of narrative, a trait already present in the first manifestations of the gothic form, but also at the level of genre (168-9). This paper will concentrate on these two types of uncertainty, both at the level of narrative and at the level of genre.

At the level of generic form the book combines characteristics coming from different sources. The book clearly draws from the language of cinema. Reproducing the plot of many slasher movies and serial-killer movies, American Psycho is the story of Patrick Bateman, a rich white heterosexual yuppie that conceals a sexist, racist, xenophobic serial killer. His victims are mainly women, black people, beggars, children, homosexuals, that is to say, those that he considers under him in his particular social scale. Both the murders and the sexual encounters are explained in a very graphic way, very much indebted to the slasher movie tradition. Some of these movies are actually mentioned in the book, like Body Double (112) or The Texas Chainsaw Massacre (153), together with other invented, very explicit titles such as Blond, Hot, Dead (229), Bloodhungry (249) or The Toolbox Murders (278). Patrick is all the time renting films and, in fact, one of his most repeated excuses to leave a place or someone is that he has to return some videotapes. His favourite films are slasher and pornographic movies, films which will inspire his horrific actions. There are other cinematic traits deployed in the book such as the narrator's use of "a slow dissolve" (8) to separate one scene from another or the "slow motion" (158) when he attempts to murder Luis, a homosexual in love with him. He even imagines some situations as they would be depicted in a film:

I am so used to imagining everything happening the way it occurs in movies, visualizing things falling somehow into the shape of events on a screen, that I almost hear the swelling of an orchestra, can almost hallucinate the camera panning low around us, fireworks bursting in slow motion overhead, the seventy-millimeter image of her lips parting and the subsequent murmur of 'I want you' in Dolby sound. (265)

This "visualizing things falling somehow into the shape of events on the screen" is something that he does in other contexts less romantic than the one described above. His sexual encounters with two women at a time are based on pornographic movies he previously rents. He finds inspiration for his murders not only in the slasher movies he rents, but also in TV programs like 'The Patty Winters Show' or in the daily news of yellow newspapers.

American Psycho not only reflects the 'gothic' language and codes of slasher films, it also draws from the language of other media that have incorporated the gothic language to their own systems. The yellow newspapers have taken the language of horror and some of their headlines could be titles for horror tales. In fact, in the 18 th century a very close connection between the yellow press and the gothic already existed. Many gothic tales were 
based on sensational news pieces. In American Psycho, Price, one of Bateman's yuppie friends, makes a summary of that day's newspaper:

'In one issue - in one issue - let's see here ... strangled models, babies thrown from tenement rooftops, kids killed in the subway, a Communist rally, Mafia boss wiped out, Nazis . . baseball players with AIDS, more Mafia shit, gridlock, the homeless, various maniacs, faggots. ...' (4)

As the narration advances some of the titles of the chapters resemble more and more the language of the yellow press: "Confronted by Faggot" (291), "Killing Child at Zoo" (296) or "Tries to Cook and Eat Girl" (343). Ellis is of course exaggerating the language of the yellow press to make readers aware of how far society has gone. The feeling left is that these titles of chapters in the book could also be yellow press headlines.

Television has also embraced the language of horror and this is reflected in the narration through the invented "The Patty Winters Show," which clearly parodies real chat shows like "The Oprah Winfrey Show." Bateman is obsessed with the program as he records it on the video and comments the title of each program. The titles vary from the superficial: "Perfumes, Lipsticks, Makeups," "Aerobic Exercise," "Salad Bars" to the most horrific subjects: "Toddler-murders," "Concentration Camp Survivors" or even one about a man who set his daughter on fire while she was giving birth. The juxtaposition of these two kinds of subject implies that society does not really make a difference between the two, at the same time showing that the 'horrific' subject of American Psycho is as horrific as the newspaper headlines' or the TV programs' contents. Nevertheless, contemporary horror is not only present in cinema, newspapers or television. The pornographic magazines also display a great deal of horror in their depiction of rape, sadistic/masochistic pleasure and even murder of women. Sex and horror became especially linked in film between 1973 and 1983 and American horror writers responded to this challenge by adopting this trend in their writings (Nicholson 252). American Psycho also uses the pornographic language of torture and abuse and, ironically enough, the book has been most harshly attacked for using this kind of code, a code that has been present in porn magazines for a long time.

As has been seen so far, in our society the language of horror has penetrated many different cultural manifestations and American Psycho combines all these languages with the most frivolous superficiality. Not getting a good table for dinner affects these yuppies more than reading the horrific headlines of the newspapers. This is Patrick's reaction when arriving at an ultra-fashionable restaurant: "I'm on the verge of tears by the time we arrive at Pastels since I'm positive we won't get seated but the table is good, and relief that is almost tidal in scope washes over me in an awesome wave" (39). After being bombarded by the horrors depicted on TV, magazines or newspapers, society is immune to them and prefers to care about superficial things that seem more real to them. The reader may recognise this attitude and identify with it and this uncanny recognition is as horrific as reading about Patrick's murders. For Mark Jancovich this is the postmodern condition, a 'survivalist' response and isolationist position from which people "seek to hold on to what little is left to them" (84). The postmodern gothic reflects this new kind of horror, this postmodern condition, which is reflected and channelled through the figure of the psychopath. 
The uncertainty present in postmodern gothic is not only seen in a generic level, that is to say, in the combination of the languages of different cultural manifestations (cinema, TV, magazines). This uncertainty is also present at a narrative level. In American Psycho it is difficult to make the distinction between normal/abnormal or order/disorder at the level of the narrative. Patrick Bateman may be a serial killer but he is at the same time the symbol of success in the 80s. Patrick Bateman is rich, handsome- he is repeatedly mistaken for a model or movie star-and successful with women-most women he meets seem to be attracted towards him. He masters the rules of fashion-his friends are repeatedly asking him what to wear or how to combine their clothes - he obtains reservations for the best restaurants and is admitted in the best night-clubs. He is a member of an exclusive health club, curiously enough called 'Xclusive,' and he lives in an expensive building, with Tom Cruise for a neighbour. For a society based on appearances Patrick Bateman represents the American dream, the utmost success. Jean Baudrillard makes an accurate description of this society obsessed with the cult of the body: dieting, body-building, jogging, with a 'look' based on clothes. This society dreams of "fashion, the latest styles, idols, the play of images, travel for its own sake, advertising. . . In short, the orgy" (96).

Bateman represents the idea of success that the society of the 80s in America had, he should be the hero of the novel but, as Mark Jancovich points out, the traditional gothic hero capable of combating the monster and protecting the victims has disappeared, the main characters are now the monsters and their victims (86), and that is what Patrick Bateman is. The distinction between normality/abnormality is undermined in the book. The reader feels the alluring power of Bateman and may even identify with or admire a lifestyle that the 80s fed in America. Even the characters of the book think that Patrick is "the boy next door" (11). In the postmodern gothic the uncertainty is so deep that the most simple distinction hero/monster becomes undefined. Jancovich points out that this may be so because the forces of rational control become the source of social problems. Supposedly normal families breed abnormal psychologies, policemen are corrupted, etc. (86). It is the very society that has crowned Bateman and his life style the one that suffers the consequences, the victim of its own superficial system of judgement.

The result of this uncertainty is that these narratives do not have a definite closure, since effective social action against the monster is impossible without changing the very foundations of that society. Jancovich marks this as a movement towards apocalypse (86). Patrick Bateman is not caught at the end, he is not punished. There is a detective investigating one of Patrick's victims: Paul Owen. Owen is another yuppie, not by coincidence a Jew, who has obtained an account Patrick wanted. The detective not only does not arrest Patrick but actually likes him. The most ironic aspect of this situation is the fact that Patrick confesses his double nature on many occasions throughout the book. However, people are so busy with their narcissistic concerns that they do not seem to hear what Patrick says. Evelyn, Patrick's girlfriend, is telling him how much she would like to marry, to which Patrick answers:

'I'd want to bring a Harrison AK-47 assault rifle to the ceremony,' I say, bored in a rush, 'with a thirty-round magazine so after thoroughly blowing your fat mother's head off with it 
I could use it on that fag brother of yours. . . ' Stopping, confused, inspecting yesterday's manicure, I look back at Evelyn. (124)

Evelyn is not affected by Patrick's words and goes on describing the ceremony, which Patrick of course notices: "She does not fully grasp a word I'm saying. My essence is eluding her" (124). The same happens when he tells Armstrong, another yuppie friend: "My life is a living hell ... and there are many more people I, uh, want to ... want to, well, I guess murder" (141). He tells Owen "I'm utterly insane" and "I like to dissect girls" (216) but nobody seems to care. The situation becomes ridiculous when, after a chase, Patrick thinks he is going to get caught and confesses all his murders in Harold's telephone machine. He is not caught but he does not need to deny what he said because Harold thinks it was a joke, he says: "Jesus, Davis. Yes, that was hilarious. That was you, was it?"(387). A society that has created a monster like Patrick cannot destroy him. Classical gothic monsters like Frankenstein or Dracula were destroyed at the end, restoring normality and stating a more or less clear moral. The monsters were freaks and society was able to destroy them. However, in this new form of gothic normality cannot be restored because normality is what Patrick represents, the normal has become the abnormal. The only solution is to destroy the whole social order, which is obviously impossible. It is not a coincidence that the book opens with the capital words: "ABANDON ALL HOPE YE WHO ENTER HERE" and finishes with "THIS IS NOT AN EXIT". The ending is not an exit because horror is present in the society we live in, a society we cannot escape by closing the book, by closing American Psycho.

American Psycho is thus a postmodern product dealing with a postmodern world. For Norman K. Denzin this postmodern world is characterised "by the cultivation of conspicuous consumption consumer lifestyles ... which stress the prestige and exchange value of appearance, civility, and personal pleasure and desire" (5). Youth, health, and sexuality have become premium values, the only values, and this is something reflected in American Psycho. The book is a social critique of the selfish and divided society of the 80s in America and to do so, the book uses a genre that allows the possibility of speaking the 'unspeakable.' As has been pointed out throughout this paper, horror is not an escapist genre but a means of conveying a social critique. The genre has changed to adapt itself to the different ideologies and readers but it has never lost its power to move and arouse the people's conscience. American Psycho can be read in two ways. At a superficial level we may have a social freak, a serial killer, a monster that kills women, homosexuals, beggars, children; at a deeper level we realise that Patrick Bateman is not a social freak but a social success and that the real monster is not one man but the whole society that has made a man like Bateman possible. There is no 'easy' explanation for Bateman's behaviour. His family was not poor, he was not abused as a child, there is no psychological explanation to account for his behaviour, as may have been the case in Hitchcock's film Psycho. The only explanation is that the society in which he lives has made him so. At the end of the book he says so himself:

Why? and automatically answering, out of the blue, for no reason, just opening my mouth, words coming out, summarizing it for the idiots: 'Well, though I know I should have done that instead of not doing it, I'm twenty-seven for Christ sakes and this is, uh, how life pres- 
ents itself in a bar or in a club in New York, maybe anywhere, at the end of the century and how people, you know, me, behave, and this is what being Patrick means to me, I guess, so, well, yup, uh ....'(399)

The reader finds a set of shared social values making unavoidable some identification with Bateman and this is what makes the social criticism of the 80s powerful and pointed. Freud's idea of the uncanny gets re-enacted in its sharpest way. The familiar that we had tried to repress, the drawbacks of a society too obsessed with appearances come back. We recognise the homeless people, the poor, the prostitutes and we feel real horror when we realise everything we share with Bateman, with the monster of the novel.

\section{WORKS CITED}

Baudrillard, Jean. America. [1988] London and New York: Verso, 1986.

Bloom, Clive, ed. Gothic. Horror. London: MacMillan, 1998.

Botting, Fred. Gothic. London and New York: Routledge, 1996.

Denzin, Norman K. Images of Postmodern Society: Social Theory and Contemporary Cinema. London: Sage Publications, 1991.

Ellis, Bret Easton. American Psycho. London: Picador, 1991.

Freud, Sigmund. "The Uncanny." [1919] Art and Literature 14. Penguin Freud Library. Harmondsworth: Penguin, 1985: 339-76.

Jancovich, Mark. Horror. London: Batsford, 1992.

Lyotard, Jean-Francois. The Postmodern Condition . [1979] Minneapolis: U of Minnesota P, 1984.

Nicholson, John. "On Sex and Horror." Gothic Horror. Ed. Clive Bloom. London: MacMillan, 1998.

Punter, David. The Literature of Terror. Vol 2 of The Modern Gothic. London and New York: Longman, 1996. 